Lianghuo Fan ${ }^{1}$

East China Normal University, Asian Centre for

Mathematics Education, Shanghai, China

University of Southampton, Southampton Education School,

Southampton, UK

$\mathrm{Na} \mathrm{Li}$

East China Normal University, Asian Centre for Mathematics Education, Shanghai, China

\title{
How are mathematicians as part \\ of mathematics history represented in contemporary Chinese school mathematics textbooks?
}

\begin{abstract}
Summary: As part of our efforts to understand how history and culture are manifested in mathematics textbooks, we investigated particularly in this study how mathematicians are represented across three different series of contemporary school mathematics textbooks used in primary and junior secondary schools in China. The study intends to document the ways of representation of mathematicians in the three series of textbooks, compare the similarities and differences, and explore the reasons and implications of the findings concerning mathematics textbook research and development. Our findings show that each series of mathematics textbooks introduced both Chinese and non-Chinese mathematicians in a commendable way, though most of the mathematicians introduced were ancient mathematicians, and all the three series introduced mathematicians each year from Grade 2 to Grade 9. There is also a high level of consistency in the distribution of the introduction of mathematicians in the three series in terms of mathematics contents and the structures of the chapters. In comparison, we found the mathematics textbook series by the PEP presented a more balanced distribution of the introductions of mathematicians in terms of grade levels, ethnic origins and the history timeline. The explanations and implications of the findings are discussed at the end of the paper.
\end{abstract}

Keywords: Mathematics textbooks, Chinese mathematics education, mathematicians in textbooks, history of mathematics, textbook analysis.

1 lhfan@math.ecnu.edu.cn

2 This study was jointly supported by two research grants awarded by East China Normal University, one from its "Happy Flowers" Strategic Research Fund (Award No: 2019ECNU-XF2H004) and the other from the Asian Centre for Mathematics Education (Award No: 92900-120215-10514).

Copyright $\odot 2020$ by the authors, licensee Teacher Education Faculty University of Belgrade, SERBIA.

This is an open access article distributed under the terms of the Creative Commons Attribution License (CC BY 4.0) (https://creativecommons.org/licenses/by/4.0/), which permits unrestricted use, distribution, and reproduction in any medium, provided the original paper is accurately cited. 


\section{Introduction and Background ${ }^{3}$}

As is well known, mathematics textbooks play an important role in the teaching and learning of mathematics in many countries. Related to this fact, mathematics textbook research has received a rapidly increasing attention from researchers over the last two decades or so in different parts of the world (e.g., see Fan et al., 2013; Schubring \& Fan, 2018). This development can be seen from the fact that, for example, ZDM published two special issues in 2013 and 2018, with the theme being "textbook research on mathematics education" and "recent advances in mathematics textbook research and development" respectively, and a highly visible conference series, the International Conferences on Mathematics Textbook Research and Development, were held in the UK in 2014 (Jones et al., 2014), Brazil in 2017 (Schubring \& Fan, 2018), and Germany in 2019 (Rezat et al., 2019).

Under the general background of mathematics textbook research, there have been a number of studies focusing on the history of mathematics in mathematics textbooks (e.g., Eren et al., 2015; Ju et al., 2016; Schorcht, 2018), and some researchers further argued that the topic of mathematicians is an aspect of the history of mathematics (e.g., Shen et al., 2013; Wang et al., 2015). However, there have been very few studies so far directly looking into the issue about how mathematicians are represented in school mathematics textbooks (e.g., see Castaneda et al., 2019), even though some researchers have argued that introducing mathematicians was a way to use history in mathematics education (cf. Fauvel, 1991).

There is no doubt that researchers have paid attention to the role of the history of mathematics in the teaching and learning of school mathematics.

3 This article is partly based on a presentation made at the Third International Conference on Mathematics Textbook Research and Development, which was held in Paderborn, Germany in 2019. Significant modifications were made, and the article also includes new data which were not available earlier. The authors would like to thank Ms Sicheng Xie for her assistance in coding the data during the study.
For example, Jones (1957) analysed the history of mathematics as a teaching tool for students' learning of mathematics. Gulikers and Blom (2001) conducted a survey of literature on the use and value of history in geometry education and they maintained that the history of mathematics could help teachers to teach mathematics and pupils to learn mathematics in many aspects, especially for pupils' learning. Furthermore, Jankvist (2009) categorized the "whys" and "hows" of using history in mathematics education, dividing the former into history as a tool and as a goal and dividing the latter into the illumination, the modules and the history-based approaches in terms of the ways of using.

The role of the history of mathematics in the teaching and learning of mathematics has also received reasonable attention in contemporary mathematics education in China. In fact, both Chinese national curriculum standards and the Shanghai mathematics curriculum standards for primary and secondary stage emphasize that the history of mathematics should be integrated into mathematics textbooks (Shanghai Municipal Education Commission, 2004; Ministry of Education of the People's Republic of China, 2011). Such ideas are also reflected in the national mathematics curriculum standards in other countries such as England (Department for Education, 2013 \& 2014), which also treat the history of mathematics, more or less, as an integral aspect of teaching of mathematics.

It is worth noting that the national curriculum standards in China particularly stressed that students can understand better, by learning from the work and spirit of mathematicians, what the rigor of mathematics means and hence benefit from their learning of mathematics. In a sense, this reflects the importance of the introduction of mathematicians in Chinese mathematics textbooks as mathematics textbooks play the most dominant role in Chinese mathematics classrooms (Fan et al., 2004).

In this study, as part of our efforts to understand how history and culture are manifested in 
mathematics textbooks (e.g., see Fan et al., 2018), we aim to particularly investigate how mathematicians are represented across three different series of contemporary school mathematics textbooks used in primary and junior secondary schools in China. By doing so, our purpose is to document the ways of representation of mathematicians in the three series of textbooks, compare the similarities and differences between them, and explore the reasons and implications of the findings concerning mathematics textbook research and development.

\section{Research Questions}

In the research, focusing on the three series of Chinese primary and junior secondary school mathematics textbooks, one published and used in Shanghai and the others published by People's Education Press and Beijing Normal University Press respectively and used in many different parts of China, we intend to address the following questions:

- How are mathematicians as part of mathematics history represented in the Chinese mathematics textbooks?

- What are the similarities and differences in the representation of mathematicians among the three series of the mathematics textbooks?

As aforementioned, by addressing these research questions, we also hope to explore the reasons and implications of the findings in relation to mathematics textbook research and development.

\section{Methods and Procedures}

\section{Textbook selection}

At present, there are two mathematics curriculum standards implemented in the stage of compulsory education in China, i.e., the Shanghai Mathematics Curriculum Standards for Primary and Secondary Schools (Trial Version) and the Mathematics
Curriculum Standards for Compulsory Education (2011 Edition). It should be noted that the Shanghai's curriculum standards is approved by the Chinese central government and implemented in virtually all primary and secondary schools in the city of Shanghai. On the other hand, the Mathematics Curriculum Standards for Compulsory Education (2011 Edition), or simply the national mathematics curriculum standards, is implemented in all the regions except Shanghai in the Chinese mainland.

The stage of compulsory education in China lasts 9 years, from primary school to junior secondary school, but the school system in Shanghai is different from other parts of China, which follow the national curriculum standards. In general, there are 6 years of primary education, followed by 3 years of junior secondary education in all the regions except Shanghai in China. In Shanghai, primary education lasts 5 years and junior secondary education lasts 4 years, so it is more comparable if we select the whole stage of compulsory education.

In this study, to investigate how primary and junior secondary school mathematics textbooks in China represent mathematicians, as mentioned earlier, we selected the three series of mathematics textbooks from Grade 1 to Grade 9. They are as follows: Series 1: The mathematics textbooks published by Juvenile \& Children's Publishing House (Grade 1-2) and Shanghai Educational Publishing House (Grade 3-9) and used in Shanghai;

Series 2: The mathematics textbooks published by the People's Educational Press;

Series 3: The mathematics textbooks published by Beijing Normal University Press.

For Shanghai, the mathematics textbooks used were developed in accordance with the Shanghai's curriculum standards. They were published by two publishers, the first and second grades' mathematics textbooks were published by Juvenile \& Children's Publishing House, while all the remaining 
seven grades' textbooks were published by Shanghai Educational Publishing House.

The mathematics textbooks published by the People's Education Press (PEP) and Beijing Normal University Press (BNUP) are two most widely used series in China in terms of the number of regions where they are used. Besides, the two series of mathematics textbooks we selected in this study were developed according to the national mathematics curriculum standards.

There are two textbooks for every grade level in all the above three series of mathematics textbooks except for Grade 9 in the Shanghai textbooks, because there is an additional textbook in Grade 9 for the enrichment of learning, which is the compulsory curriculum for every student who uses the series.

\section{Process}

After selecting the textbooks, we used the content analysis method and examined all the textbooks to address the research questions mentioned above with focus on the following aspects.

- Regarding how mathematicians are represented in the mathematics textbooks, we focused on how the topics of mathematicians are distributed in the textbooks in terms of the grade level, mathematical content, the structure of chapters in the textbooks, the nationality and the periods of time.

- Regarding the similarities and differences on the representation of mathematicians among the three series of textbooks, we further examined the textbooks from the perspective of comparison in terms of the distribution as mentioned above.

More specifically, focusing on the representation of mathematicians in the selected textbooks, we identified the mathematicians by their names appearing in the textbooks by reading the three series of mathematics textbooks. It should be noted that the portraits and pictures of mathematicians are also included in this study, but some mathematical terms with mathematicians' names, for example, Pythagoras' Theorem, Heron-Qin Jiushao ${ }^{4}$ Formula and so on, were not taken into consideration in the study.

We looked at the distribution in the following aspects by counting the numbers of pages, the paragraphs where mathematicians appear and the number of times mathematicians were mentioned in the selected textbooks. In this regard, we firstly analysed the distribution of mathematicians from Grade 1 to Grade 9. Secondly, consistent with the Chinese national curriculum standards, we divided mathematical contents into the three broad areas: number and algebra, shape and geometry, and probability and statistics. Thirdly, we analysed each chapter in the textbooks in terms of the introduction, main texts, examples, exercises and reading materials. Finally, we categorised the nationalities or ethnic origins of the mathematicians introduced in the textbooks into Chinese and non-Chinese in terms of the periods of time, i.e., ancient time (before 1840), modern time (1840-Semptember 1949) and contemporary time (October 1949-present), which is based on the commonly used division of the timelines of the Chinese history in China.

To ensure reliability of the coding, we invited an external coder to code the number of times mathematicians were mentioned in the mathematics textbooks of both the Shanghai series and the PEP series, and we got a high consistency with agreement of 0.988 and 0.993 respectively, which indicates that the data collected from the coding is highly reliable.

\section{Findings and Discussions}

The findings of the study are reported below in four aspects of the distributions of the introduction of mathematicians in the three series of the mathematics textbooks, i.e., the distribution across the grade level, the distribution across mathematics

4 Qin Jiushao (1208-1268) is an ancient Chinese mathematician living in the Song Dynasty. 
content areas, the distribution in terms of the structure of chapters, and the distribution in terms of ethnic origins and timelines of history.

1. How the introductions of mathematicians are distributed across the grade levels

The distribution of the introductions of mathematicians in the three series of mathematics textbooks across the different grade levels is showed in Table 1.

It can be seen from Table 1 that among the textbooks of each selected series, pages where mathematicians are mentioned account for no more than $2 \%$ of the total number of pages. In other words, it is common for the three series that the contents related to the topic of mathematicians take up a very small percentage of the entire series. To us, this result is largely expected and understandable as the main intention of introducing the topic of mathematicians into school mathematics textbooks is to help pupils learn mathematics instead of mathematicians; after all, these are textbooks of school mathematics, not mathematics history.

Among the three series of mathematics textbooks, the PEP mathematics textbooks used the largest number of pages to introduce mathematicians and its proportion in the total number of pages is also the largest. In comparison, the number of pages where mathematicians were introduced in the Shanghai mathematics textbooks is the smallest. In fact, it is almost half the number in the textbooks published by PEP. In a sense, this also explains why the total number of pages in the Shanghai mathematics textbooks is the smallest. Nevertheless, although the pages where mathematicians were mentioned in the textbooks published by BNUP are more than the Shanghai textbooks, these pages take up $1.37 \%$ and $1.34 \%$ of the total number of pages in the two series respectively. In other words, the proportions

Table 1. Distribution of the introductions of mathematicians across the different grade levels in the selected textbooks.

\begin{tabular}{|c|c|c|c|c|c|c|c|c|c|c|c|}
\hline Grad & & 1 & 2 & 3 & 4 & 5 & 6 & 7 & 8 & 9 & Total \\
\hline \multirow{2}{*}{ Shanghai } & Pages & $\begin{array}{c}0 \\
(0)\end{array}$ & $\begin{array}{c}1 \\
(0.62)\end{array}$ & $\begin{array}{c}1 \\
(0.62)\end{array}$ & $\begin{array}{c}1 \\
(0.55)\end{array}$ & $\begin{array}{c}1 \\
(0.51)\end{array}$ & $\begin{array}{c}6 \\
(2.40)\end{array}$ & $\begin{array}{c}3 \\
(1.18)\end{array}$ & $\begin{array}{c}9 \\
(3.24)\end{array}$ & $\begin{array}{c}3 \\
(1.22)\end{array}$ & $\begin{array}{c}25 \\
(1.34)\end{array}$ \\
\hline & Times & $\begin{array}{c}0 \\
(0) \\
\end{array}$ & $\begin{array}{c}1 \\
(1) \\
\end{array}$ & $\begin{array}{c}1 \\
(1) \\
\end{array}$ & $\begin{array}{c}2 \\
(2) \\
\end{array}$ & $\begin{array}{c}3 \\
(1) \\
\end{array}$ & $\begin{array}{c}13 \\
(7) \\
\end{array}$ & $\begin{array}{c}8 \\
(4) \\
\end{array}$ & $\begin{array}{c}33 \\
(12) \\
\end{array}$ & $\begin{array}{c}4 \\
(4) \\
\end{array}$ & $\begin{array}{c}65 \\
(25) \\
\end{array}$ \\
\hline \multirow{2}{*}{ PEP } & Pages & $\begin{array}{c}0 \\
(0)\end{array}$ & $\begin{array}{c}2 \\
(0.87)\end{array}$ & $\begin{array}{c}1 \\
(0.43)\end{array}$ & $\begin{array}{c}3 \\
(1.27)\end{array}$ & $\begin{array}{c}4 \\
(1.65)\end{array}$ & $\begin{array}{c}7 \\
(2.99)\end{array}$ & $\begin{array}{c}14 \\
(4.44)\end{array}$ & $\begin{array}{c}8 \\
(2.68)\end{array}$ & $\begin{array}{c}10 \\
(3.76)\end{array}$ & $\begin{array}{c}49 \\
(2.16)\end{array}$ \\
\hline & Times & $\begin{array}{c}0 \\
(0) \\
\end{array}$ & $\begin{array}{c}3 \\
(2) \\
\end{array}$ & $\begin{array}{c}1 \\
(1) \\
\end{array}$ & $\begin{array}{l}10 \\
(6) \\
\end{array}$ & $\begin{array}{c}8 \\
(5) \\
\end{array}$ & $\begin{array}{l}11 \\
(6) \\
\end{array}$ & $\begin{array}{c}35 \\
(14) \\
\end{array}$ & $\begin{array}{c}34 \\
(15) \\
\end{array}$ & $\begin{array}{c}32 \\
(11) \\
\end{array}$ & $\begin{array}{l}134 \\
(43) \\
\end{array}$ \\
\hline \multirow{2}{*}{ BNUP } & Pages & $\begin{array}{c}0 \\
(0)\end{array}$ & $\begin{array}{c}1 \\
(0.46)\end{array}$ & $\begin{array}{c}3 \\
(1.42)\end{array}$ & $\begin{array}{c}2 \\
(0.91)\end{array}$ & $\begin{array}{c}4 \\
(1.79)\end{array}$ & $\begin{array}{c}2 \\
(0.89)\end{array}$ & $\begin{array}{c}6 \\
(1.62)\end{array}$ & $\begin{array}{c}8 \\
(2.15)\end{array}$ & $\begin{array}{c}6 \\
(1.99)\end{array}$ & $\begin{array}{c}32 \\
(1.37)\end{array}$ \\
\hline & Times & $\begin{array}{c}0 \\
(0) \\
\end{array}$ & $\begin{array}{c}4 \\
(1) \\
\end{array}$ & $\begin{array}{c}8 \\
(3) \\
\end{array}$ & $\begin{array}{c}3 \\
(2) \\
\end{array}$ & $\begin{array}{c}7 \\
(4) \\
\end{array}$ & $\begin{array}{l}10 \\
(3) \\
\end{array}$ & $\begin{array}{c}20 \\
(12) \\
\end{array}$ & $\begin{array}{l}16 \\
(9) \\
\end{array}$ & $\begin{array}{c}13 \\
(10) \\
\end{array}$ & $\begin{array}{c}81 \\
(29) \\
\end{array}$ \\
\hline
\end{tabular}

Note: ${ }^{1}$ Each figure in the brackets in the rows of "Pages" in the table above refers to the percentage that the number of pages where mathematicians were mentioned takes up in all the pages of each series of mathematics textbooks in each grade level, e.g., "(0.62)" means $0.62 \%$.

${ }^{2}$ Each figure in the brackets in the rows of "Times" in the table above refers to the number of different mathematicians who appear in each series of mathematics textbooks in each grade level.

${ }^{3}$ Each figure in the first rows of "Times" in the table above refers to the number of the names of mathematicians appearing in each series of mathematics textbooks in each grade level. 
of the topic of mathematicians in both the Shanghai textbooks and the BNUP textbooks are very close. A similar finding about the number of different mathematicians introduced was also observed in the three series of textbooks, i.e., the mathematics textbooks published by PEP introduced the largest number of mathematicians, more than 1.5 times the number in any of the other two series.

The study also looked at the number of paragraphs mentioning mathematicians on each page where mathematicians were introduced, as an indicator of how long mathematicians were actually introduced each time. The results show that the average length of the introduction of mathematicians in the three series of textbooks are all more than 1.5 paragraphs, and from the longest to the shortest, it is the PEP textbooks, the Shanghai textbooks and the BNUP textbooks. Furthermore, the average length in the first two series of textbooks are slightly over 2 paragraphs, and this descending order is consistent with the order of the number of times introducing mathematicians on each page where the topics of mathematicians were introduced, with the average number of the times in each of the three series is slightly over 2.5 times.

Further examining the distribution of the introduction of mathematicians across all the nine grades, we can see that all three series of textbooks start to introduce the topic from Grade 2, though the mathematicians introduced in Grade 2 of the three series are all different. Figure 1 shows an example introducing a Chinese mathematician ZU Chongzhi,

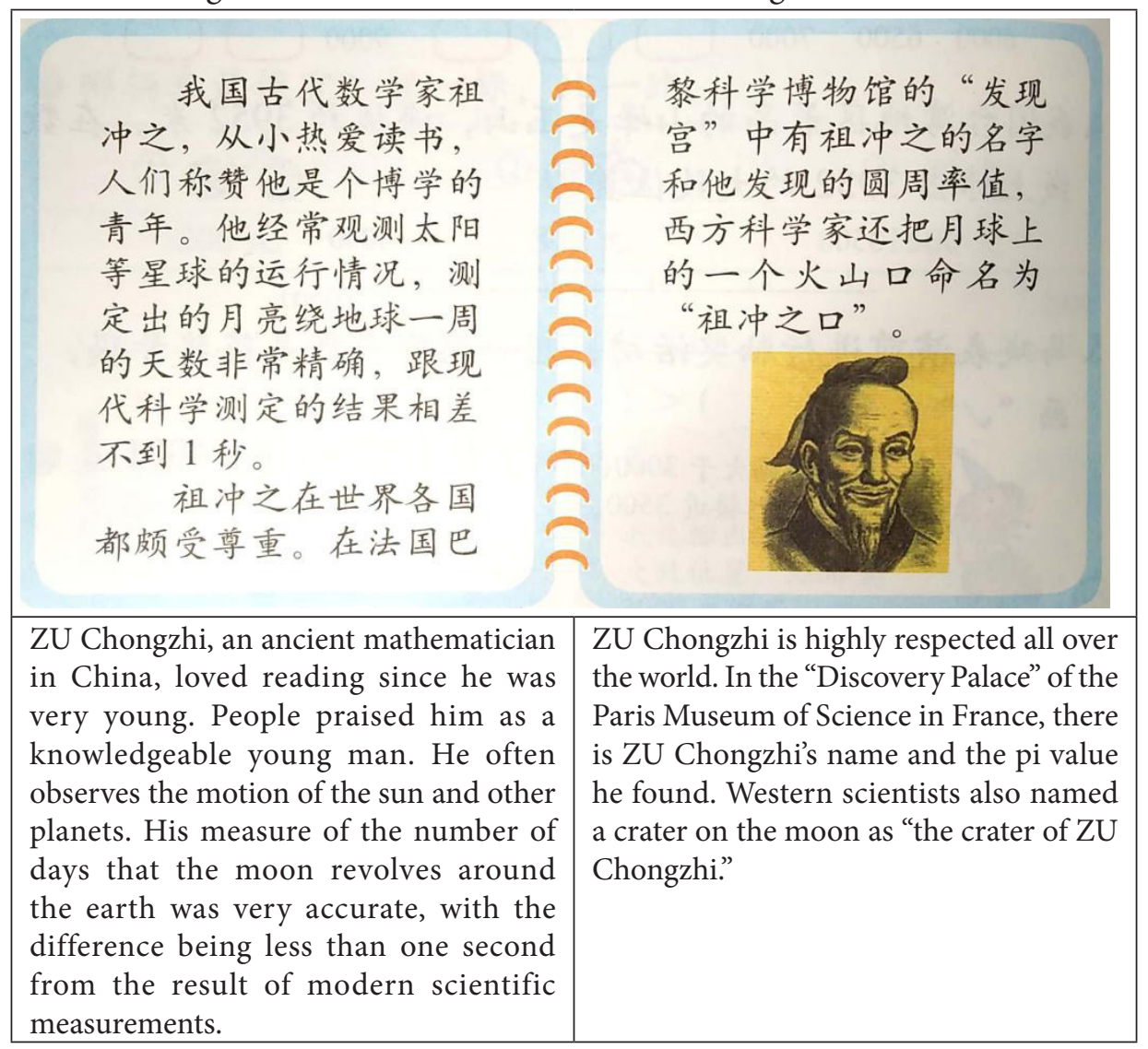

Figure 1. A reading material introducing a well-known ancient Chinese mathematician at Grade 2 from the BNUP series (Wang \& Qian, 2014: 30). 
found in the third chapter, "Large Number in Life", in the BNUP mathematics textbooks for the second semester of Grade 2.

It was also found that, although the introductions of mathematicians in all the three series is widely spread over both primary and junior secondary stages, they are much more heavily concentrated in the junior high school stage. This distribution is understandable as, in comparison with the primary stage, the junior secondary stage covers more mathematics contents, especially those with well known historical roots which are largely linked to mathematicians. In addition, the presentations of mathematicians in all the three series at the primary stage were consistently found with shorter paragraphs and fewer words, compared with the junior secondary stage. It appears clear to us this is related to the cognitive levels of pupils at different stages of learning.

How the introductions of mathematicians are distributed across different mathematics content areas

Table 2 presents a summary of the results about the distribution of the introductions of mathematicians across different mathematics content areas.

As shown in Table 2, although the PEP mathematics textbooks introduced more mathematicians than the other two textbooks, the introductions of mathematicians in all three series of mathematics textbooks are concentrated highly consistently in two areas: the first is "number and algebra" and the second is "shape and geometry".

In contrast, the introduction of mathematicians in the area of "probability and statistics" is very little, and in particular there are no mathematicians mentioned in the textbooks published by BNUP, which in our view is not ideal. On the other hand, it should be pointed out that the result is to some extent not surprising, as the content of probability and statistics only takes up a small percentage in the curriculum for the compulsory education stage in China.

It was also noticeable that some mathematicians were introduced a few times in each series of the textbooks and in different topics, indicating those mathematicians made contributions to the advancement of mathematics in different areas and/ or have special historical and cultural values in the learning of mathematics. A particular case of this treatment is LIU Hui, a great ancient Chinese mathematician, who was introduced in two areas, namely, "number and algebra" and "shape and geometry".

Table 2. Distribution of the introductions of mathematicians in terms of mathematics contents.

\begin{tabular}{ccccc}
\hline \multicolumn{2}{c}{ Mathematics content } & Number and algebra & Shape and geometry & Probability and statistics \\
\hline \multirow{3}{*}{ Shanghai } & Pages & 14 & 10 & 1 \\
& Paras & 23 & 29 & 1 \\
& Times & 28 & 36 & 1 \\
\hline \multirow{3}{*}{ PEP } & Pages & 24 & 23 & 4 \\
& Paras & 52 & 57 & 4 \\
\hline \multirow{3}{*}{ BNUP } & Times & 57 & 73 & 0 \\
& Pages & 16 & 15 & 0 \\
& Paras & 28 & 29 & 0 \\
\hline
\end{tabular}

Note: A Chinese mathematician, HUA Luogeng, is introduced one time in the preface of the mathematics textbook published by BNUP for the second semester of Grade 5 and it doesn't relate to any specific mathematics content, so it was not included in the table. 
Figure 2 and Figure 3 show how LIU Hui was introduced in the textbooks, with one from the chapter of "Meaning and Nature of Decimals" in the PEP mathematics textbooks for the second semester of Grade 4, and the other from the chapter of "Circle and Sector" in the Shanghai mathematics textbooks for the first semester of Grade 6.

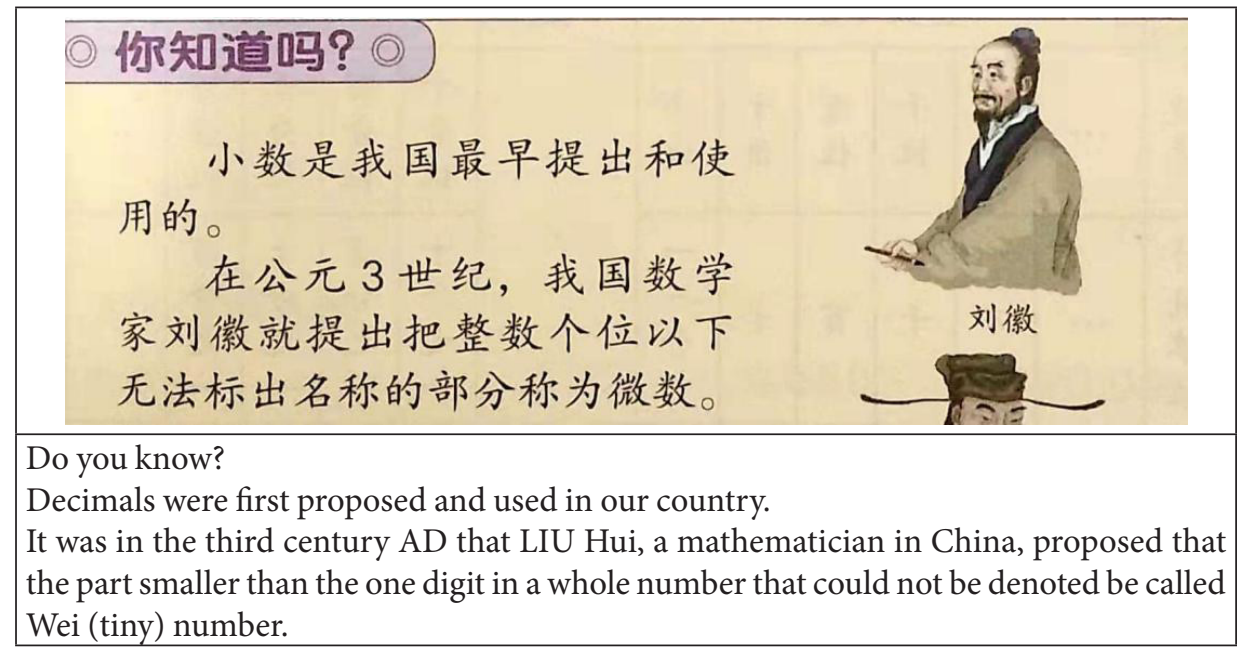

Figure 2. A reading material introducing Hui LIU in the PEP series (Lu \& Yang, 2014: 33).

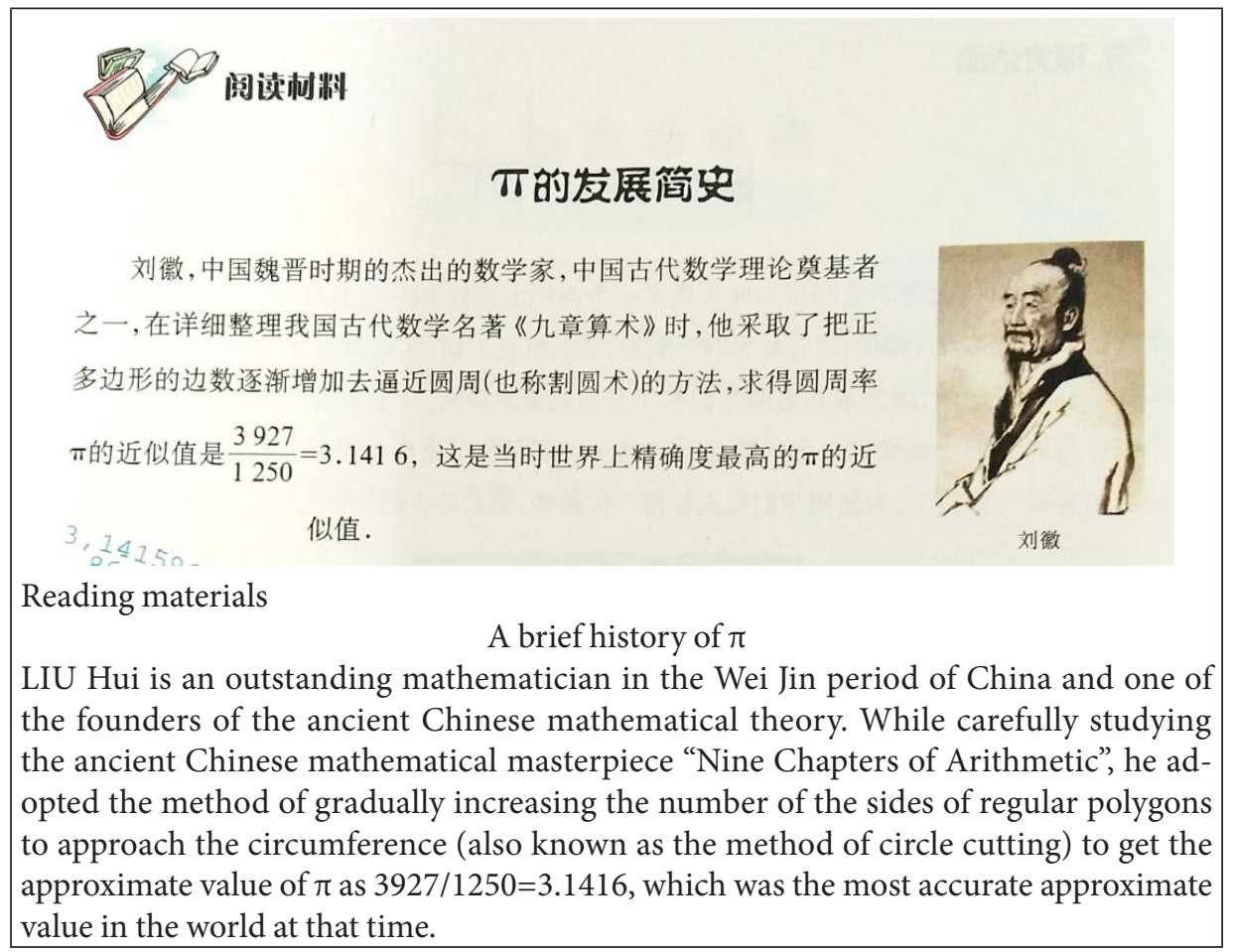

Figure 3. A reading material introducing LIU Hui in the Shanghai series (Huang, 2015: 120). 
It is also interesting to know that the numbers of pages and paragraphs where LIU Hui was mentioned and the number of times LIU Hui was mentioned in each of the three series were almost evenly distributed across the two parts, i.e., "number and algebra" and "shape and geometry". In a sense, it suggests that LIU Hui's contribution and its related educational value in terms of the history of mathematics are commonly recognized by the textbook developers of all the three series of textbooks.

How the introductions of mathematicians are distributed in terms of structure of the chapters

The study further looked at where mathematicians were introduced in each chapter of the textbooks across the three series. The results are shown in Table 3.

In Table 3 we can see that the introduction of mathematicians in all the three series of mathe- matics textbooks is predominantly found in reading materials, and we think it is understandable as students can learn more about mathematicians by reading materials than in other ways. In fact, many reading materials provided in the textbooks were intended to introduce mathematics culture and history related to the mathematics contents covered in the chapter.

Apart from the reading materials, the three series introduced mathematicians in different places in the chapters and a considerable difference exists across these three series, as shown in Table 3.

Figure 4 and Figure 5 provide two related examples, showing how the same ancient great Greek mathematician, Diophantus, was introduced in the PEP and BNUP textbooks, both in the same chapter, "linear equation with one unknown", in the first semester of Grade 7.

Table 3. Distribution of the introductions of mathematicians in terms of structure.

\begin{tabular}{ccccccc}
\hline \multicolumn{2}{c}{ Textbook series } & $\begin{array}{c}\text { Chapter } \\
\text { introduction }\end{array}$ & Main texts & Examples & Exercises & Reading materials \\
\hline \multirow{3}{*}{ Shanghai } & Pages & 1 & 6 & 0 & 1 & 17 \\
& Paras & 5 & 7 & 0 & 1 & 40 \\
& Times & 6 & 8 & 0 & 1 & 50 \\
\hline \multirow{3}{*}{ PEP } & Pages & 0 & 9 & 1 & 6 & 33 \\
& Paras & 0 & 19 & 1 & 14 & 99 \\
\hline \multirow{3}{*}{ BNUP } & Times & 0 & 20 & 1 & 14 & 26 \\
& Pages & 2 & 1 & 1 & 2 & 69 \\
\hline
\end{tabular}


13. (古代问题) 希腊数学家丢番图(公元 3-4 世纪)

的墓碑上记载着:

“他生命的六分之一是幸福的童年;

再活了他生命的十二分之一, 两规长起了细细 的胡须;

他结了婚, 又度过了一生的七分之一;

再过五年, 他有了儿子, 感到很幸福;

可是儿子只活了他父亲全部年龄的一半;

儿子死后, 他在极度悲痛中度过了四年, 也与

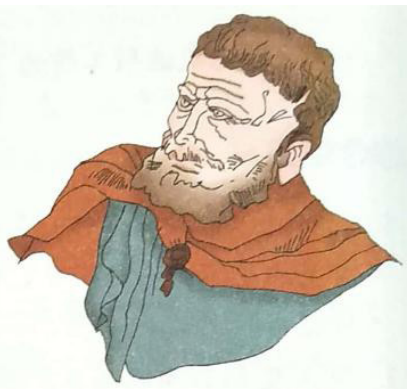

丢番图

世长辞了.”

根据以上信息, 请你算出:

(1) 丢番图的寿命;

（2）丢番图开始当爸爸时的年龄;

(3) 儿子死时丢番图的年龄.

13. (Ancient problem) Diophantus is a mathematician in Greece (between the third century AD and the fourth century $\mathrm{AD}$ ), and his tombstone tells:

"His boyhood lasted one sixth of his life; his beard grew after one twelfth more of his life; he married after one seventh of his life more; and his son was born 5 years later; the son lived to half of his father's age, and the father died 4 years after the son."

Based on the information above, please work out:

(1) the life span of Diophantus;

(2) the age of Diophantus when he became a father;

(3) the age of Diophantus when his son died.

Figure 4. An exercise about Diophantus from the PEP series (Li, 2012: 108).

In the above examples, both series used the same Diophantus's life story (though with slightly different Chinese translations) and provided the same question about the life of Diophantus, but the PEP mathematics textbook treated it as an exercise with two additional questions as part of students' review of the chapter they have learned, while the BNUP textbook used it as an introduction to open the chapter for students to learn. It is clear from the examples that there are different ways to present mathematicians in the textbooks.
How the introductions of mathematicians are distributed in terms of ethnic origins and timelines of history

Finally, the study examined the distribution of the introduction of mathematicians in terms of ethnic origins and the timelines of history across the three series of the textbooks. The results are shown in Table 4.

As we can see in Table 4, most mathematicians introduced in the three series belong to ancient times and most of them are non-Chinese; and only a very small number of mathematicians introduced in the textbooks belong to the modern and contemporary times, which is particularly the case in the Shanghai textbooks and the BNUP textbooks. 


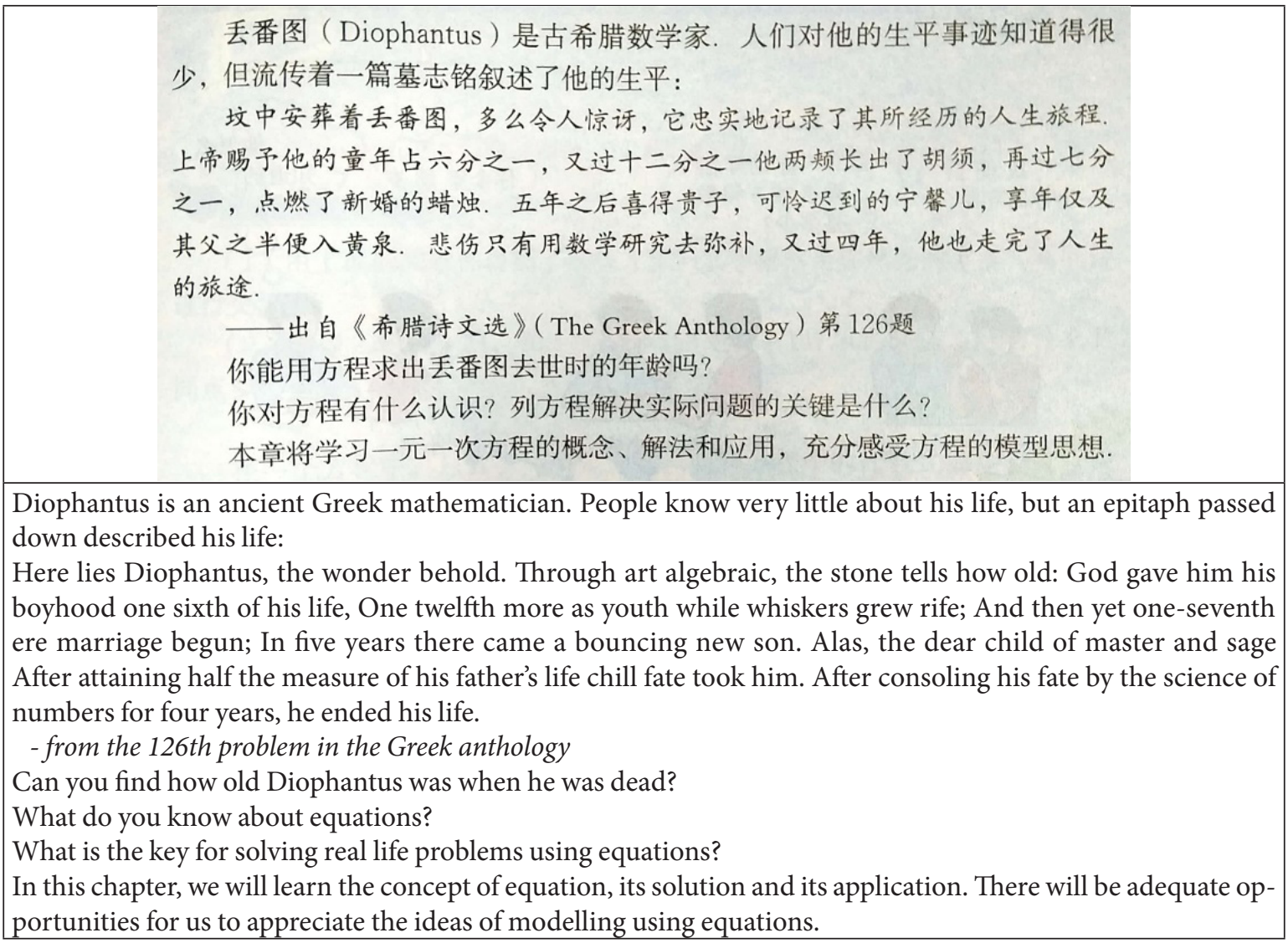

Figure 5. An introduction of the chapter about Diophantus from the BNUP series (Gu, 2013: 129).

Table 4. Distribution of the introductions of mathematicians in terms of ethnic origins in timeline of history.

\begin{tabular}{cccccccc}
\hline \multirow{2}{*}{$\begin{array}{c}\text { Timeline of history } \\
\text { Nationality }\end{array}$} & Chinese & Non-Chinese & Chinese & Non-Chinese & \multicolumn{2}{c}{ Contemporary } \\
Chinese & Non-Chinese \\
\hline \multirow{3}{*}{ Shanghai } & Pages & 9 & 17 & 0 & 1 & 2 & 0 \\
& Paras & 22 & 26 & 0 & 2 & 3 & 0 \\
& Times & 29 & 31 & 0 & 2 & 3 & 0 \\
\hline \multirow{3}{*}{ PEP } & Pages & 17 & 30 & 1 & 4 & 4 & 5 \\
& Paras & 28 & 66 & 3 & 3 & 3 & 0 \\
& Times & 32 & 76 & 3 & 4 & 3 & 0 \\
\multirow{3}{*}{ BNUP } & Pages & 12 & 22 & 2 & 2 & 3 & 0 \\
& Paras & 10 & 32 & 2 & 1 & 3 & 0 \\
\hline
\end{tabular}

Note: ${ }^{1}$ In this study, we adopted the commonly used definition of timelines of history in China, i.e., Ancient: before 1840 , Modern: 1840-1949, and Contemporary: after 1949.

${ }^{2}$ There are some overlaps on the numbers of pages as the result of the different classifications. 
At the same time, it can also be observed in Table 4 that more mathematicians introduced who belong to ancient times are non-Chinese in all the three series of mathematics textbooks in terms of the three indicators in the above table.

It is also clear that there exist considerable differences in the introduction of mathematicians, particularly those in modern and contemporary times, across the three series. In comparison, the PEP textbooks present a more widely spread distribution of the introduction of mathematicians both in terms of ethnic origins and in terms of the timelines of history, which to us is commendable and probably related to the textbook developers' experiences and guiding principles.

\section{Summary and concluding remarks}

This study examined how mathematicians are represented in three series of Chinese mathematics textbooks at the primary and secondary levels. The results revealed that starting from Grade 2, the three series of the Shanghai mathematics textbooks, the PEP mathematics textbooks and the BNUP mathematics textbooks all paid some attention to the introductions of mathematicians across the different grade levels. On the other hand, all the series paid more attention in the junior secondary school stage as compared with the primary school stage, which we think is clearly related to the content of mathematics for students to learn in the two different stages.

In terms of mathematics contents, the introductions of mathematicians in all the three series are concentrated in the topics of "number and algebra" and "shape and geometry". In terms of the structure of chapters, most mathematicians were introduced in the reading materials instead of the other parts. The former is consistent with the distribution of mathematics contents in mathematics curriculum standards at the compulsory education stage, while a possible reason for the latter is that students can learn more about mathematicians by reading materials than other ways.

We think it is commendable that each of the Shanghai, PEP and BNUP series introduced both Chinese and non-Chinese mathematicians, though most of the mathematicians introduced are ancient mathematicians, which in our view is understandable as the knowledge covered in the school textbooks is mainly basic knowledge in mathematics that mankind has known or discovered since ancient times.

From a comparative perspective, the mathematics textbooks published by PEP introduced the most mathematicians, which largely suggests that the PEP series paid more attention to the introduction of mathematicians, as compared with the other two series.

Furthermore, it appears clear to us that the mathematics textbook series by the PEP presented a more balanced distribution of the introductions of mathematicians in terms of grade levels, ethnic origins and the timeline of history. It would be interesting to find out what are the reasons behind the different treatments as mentioned earlier, which is beyond the scope of this study and deserves further investigation, e.g., through interviewing the authors of these series of school mathematics textbooks to know their views about the values and methods of integrating the topic of mathematicians into school mathematics textbooks and why they treated it in this way or that way. In addition, it is also worth exploring how different treatments of the topic of mathematicians would impact teachers' teaching and students' learning of mathematics in classroom. 


\section{References}

- Castaneda, A., Aguilar, M., Gómez-Blancarte, A., Romo-Vázquez, A., Lezama-Andalón, J. \& Miranda-Viramontes, I. (2019). Representations of mathematicians in lower secondary mathematics textbooks. Eurasia Journal of Mathematics, Science and Technology Eductaion, 15 (7), 1716. https://doi.org/10.29333/ejmste/106056

- Department for Education (2013). Mathematics programmes of study: key stages 1 and 2 (National curriculum in England). Retrieved November 13, 2019. from www: https://assets.publishing.service.gov.uk/government/uploads/system/uploads/attachment_data/file/335158/PRIMARY_national_curriculum_-_Mathematics_220714.pdf.

- Department for Education (2013). Mathematics programme of study: key stage 3 (National curriculum in England). Retrieved November 13, 2019. from www: https://assets.publishing.service.gov.uk/government/ uploads/system/uploads/attachment_data/file/239058/SECONDARY_national_curriculum_-_Mathematics.pdf.

- Department for Education (2014). Mathematics programmes of study: key stage 4 (National curriculum in England). Retrieved November 13, 2019. from www: https://assets.publishing.service.gov.uk/government/ uploads/system/uploads/attachment_data/file/331882/KS4_maths_PoS_FINAL_170714.pdf.

- Eren, M., Bulut, M. \& Bulut, N. (2015). A content analysis study about the usage of history of mathematics in textbooks in Turkey. Eurasia Journal of Mathematics, Science and Technology Eductaion, 11 (1), 53-62. https://doi.org/10.12973/eurasia.2015.1305a

- Fan, L., Chen, J., Zhu, Y., Qiu, X. \& Hu, Q. (2004). Textbook use within and beyond Chinese mathematics classrooms: A study of 12 secondary schools in Kunming and Fuzhou of China. In: Fan, L., Wong, N. Y., Cai, J. \& Li, S. (Eds.). How Chinese learn mathematics: Perspectives from insiders (228-261). Singapore: World Scientific.

- Fan, L., Zhu, Y. \& Miao, Z. (2013). Textbook research in mathematics education: development status and directions. ZDM - The International Journal on Mathematics Education, 45 (5), 633-646. DOI: 10.1007/s11858013-0539-x

- Fan, L., Xiong, B., Zhao, D. \& Niu, W. (2018). How is cultural influence manifested in the formation of mathematics textbooks? A comparative case study of resource book series between Shanghai and England. ZDM - The International Journal on Mathematics Education, 50 (5), 787-799. https://doi.org/10.1007/s11858018-0976-7

- Fauvel, J. (1991). Using history in mathematics education. For the Learning of Mathematics, 11 (2), 3-6.

- Gu, J. (Ed.). (2013). Mathematics (First semester of Grade 7). Beijing: Beijing Normal University Press. [In Chinese].

- Gulikers, I. \& Blom, K. (2001). A historical angle: A survey of recent literature on the use and value of history in geometrical education. Educational Studies in Mathematics, 47 (2), 223-258. https://doi. org/10.1023/A:1014539212782

- Huang, H. (Ed.). (2015). Mathematics (Trial version; First semester of Grade 6). Shanghai: Shanghai Educational Publishing House (In Chinese). 
- Jankvist, U. T. (2009). A categorization of the "whys" and "hows" of using history in mathematics education. Educational Studies in Mathematics, 71 (3), 235-261.

- Jones, P. S. (1957). The history of mathematics as a teaching tool. The Mathematics Teacher, 50 (1), 59-64.

- Jones, K., Bokhove, C., Howson, G. \& Fan, L. (Eds.) (2014). Proceedings of the International Conference on Mathematics Textbook Research and Development. Southampton, UK: University of Southampton.

- Ju, M., Moon, R. \& Song, J. (2016). History of mathematics in Korean mathematics textbooks: Implication for using ethnomathematics in culturally diverse school. International Journal of Science and Mathematics Education, 14 (7), 1321-1338. DOI: 10.1007/s10763-015-9647-0

- Li, H. (Ed.). (2012). Mathematics (First semester of Grade 7). Beijing: People's Education Press. [In Chinese]

- Lu, J. \& Yang, G. (Eds.). (2014). Mathematics (Second semester of Grade 4). Beijing: People’s Education Press. [In Chinese]

- Ministry of Education of the People's Republic of China (2011). Mathematics Curriculum Standards for Compulsory Education (2011 Edition). Beijing: Beijing Normal University Press. [In Chinese]

- Rezat, S., Fan, L., Hattermann, M., Schumacher, J. \& Wuschk, H. (Eds.) (2019). Proceedings of the Third International Conference on Mathematics Textbook Research and Development (ICMT-3). Paderborn, Germany: University of Paderborn.

- Shanghai Municipal Education Commission (2004). Shanghai Mathematics Curriculum Standard for Primary and Secondary Schools (Trial Version). Shanghai: Shanghai Educational Publishing House (In Chinese).

- Schorcht, S. (2018). History of mathematics in German mathematics textbooks. In: Clark, K. M., Kjeldsen, T. H., Schorcht, S. \& Tzanakis, C. (Eds.). Mathematics, Education and History, ICME-13 Monographs (143-162). Cham: Springer. https://doi.org/10.1007/978-3-319-73924-3_8.

- Schubring, G. \& Fan, L. (2018). Recent advances in mathematics textbook research and development: An overview. ZDM - The International Journal on Mathematics Education, 50 (5), 765-771. https://doi. org/10.1007/s11858-018-0979-

- Schubring, G., Fan, L. \& Giraldo, V. (Eds.) (2018). Proceedings of the Second International Conference on Mathematics Textbook Research and Development (ICMT-2). Rio de Janeiro, Brazil: Federal University of Rio de Janeiro.

- Shen, C., Liu, D. \& Wang, X. (2013). "Simple solid figures" of high school mathematics textbooks in China, Singapore, America and France. Journal of Mathematics Education, 22 (4), 30-33. [In Chinese]

- Wang, J., Wang, X. \& Hong, Y. (2015). A comparative study on mathematical culture in Chinese, French and American high school textbooks. Exploring Education Development, (20), 28-32. DOI: 10.14121/j.cnki.10083855.2015.20.007 [In Chinese]

- Wang, M. \& Qian, S. (2014). Mathematics (First semester of Grade 2). Beijing: Beijing Normal University Press. [In Chinese] 


\section{Лиангхуо Фан}

Државни универзитет Источне Кине, Азијски центар за математичко образовање, Шангај, Кина

Универзитет Саутемптон, Педагошки факултет у Саутемптону, Саутемптон, Велика Британија

\section{На Ли}

Државни универзитет Источне Кине, Азијски центар за математичко образовање, Шангај, Кина

\section{КАКО СУ МАТЕМАТИЧАРИ КАО ДЕО ИСТОРИЈЕ МАТЕМАТИКЕ ПРЕДСТАВЉЕНИ У САВРЕМЕНИМ КИНЕСКИМ УЏБЕНИЦИМА МАТЕМАТИКЕ?}

У оквиру истираживаюа о уибеницима маиемайике, која су у йослеgюе gве gеценије йривукла йажну научника широм йланеиее збой важне улоїе коју уијеници имају у насииави матемемайике (нйр. Fan et al., 2013; Schubring \& Fan, 2018), има мноіо истираживана која се баве исиоријом матемемаиике у уибеницима за овај иреgмети (нйр. Eren et al., 2015; Ju et al., 2016; Schorcht, 2018). Неки истираживачи су иили корак gатье ииврgећи gа су матиемаитичари

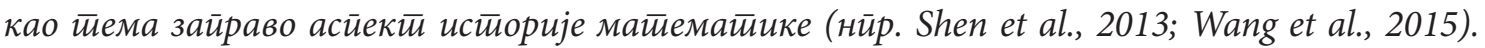

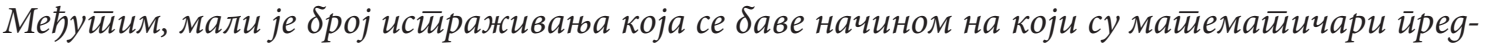
сииавлени у школским уибеницима майемайике (виgи у Castaneda et al., 2019), иако неки

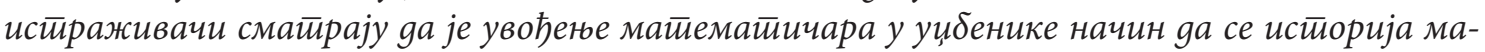
иематиике користии у матемайичком образоватьу (уй. Fauvel, 1991).

Као gео наших настиојаға gа разумемо како се истиорија и кулитура манифестиују у уибеницима матемеатике, у овом истираживану иоосебно смо истираживали како су матема-

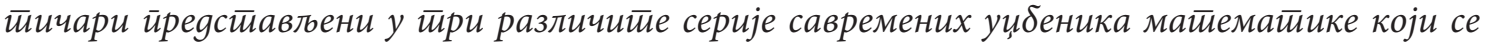
користие у основним школама и нижим разреgима среgне школе у Кини. Постиавили смо gва истираживачка иичииана:

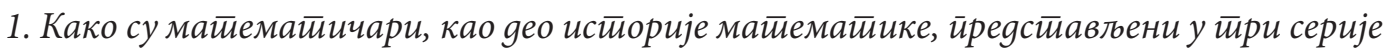
савремених кинеских уибеника матеммаиике?

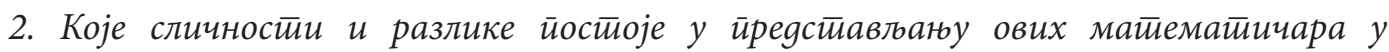
уиденицима?

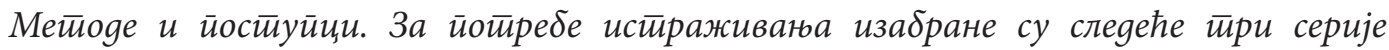
уибеника математикке:

Серија 1: Уибеници матемаииике у изgағу Shanghai Juvenile and Children Publishing House (Paspeg 1.-2.) u Shanghai Education Publishing House (paspeg 3.-9.);

Серија 2: Уибеници маиеемаиике у изgаюу People's Educational Press (PEP);

Серија 3: Уибеници маиеммайике у изgағьу Beijing Normal University Press. 
После селекиије уибеника користиили смо метиоgу анализе саяржаја и анализирали

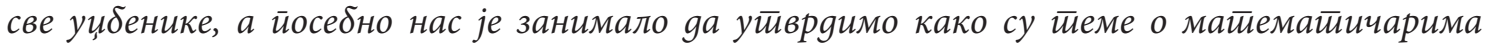

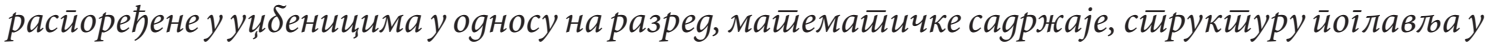

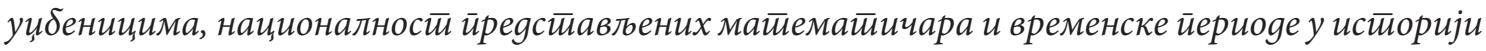
матиематичке.

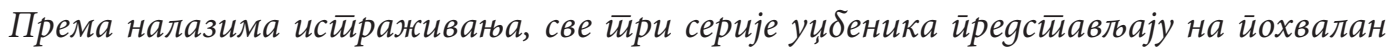

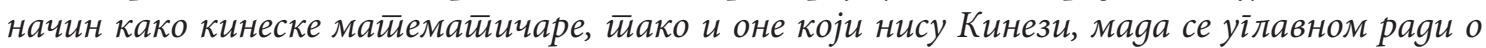

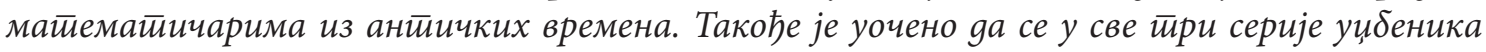

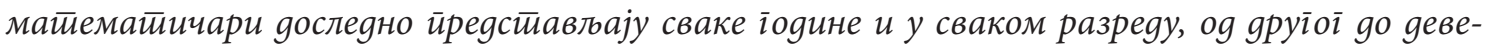

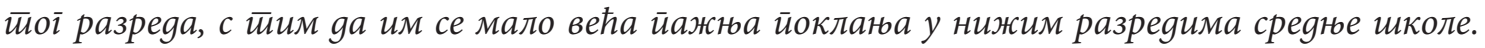

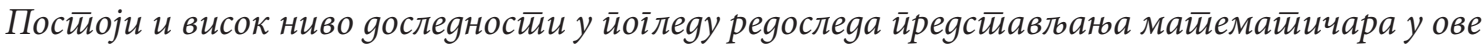

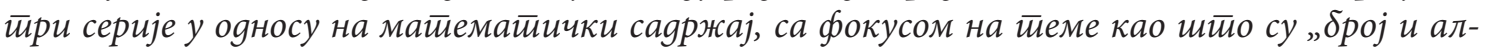

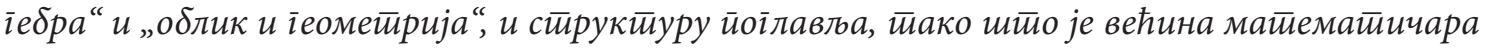

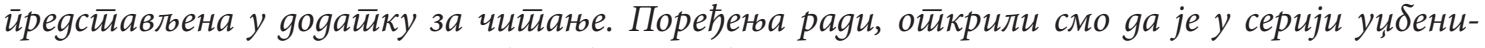

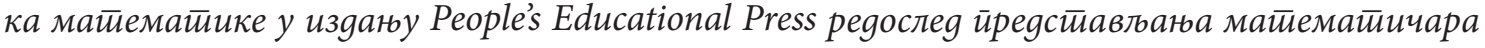
уравнойеженији у йоіллеgу нивоа разреgа, еитнчкой йорекла и временске тиније. Било би

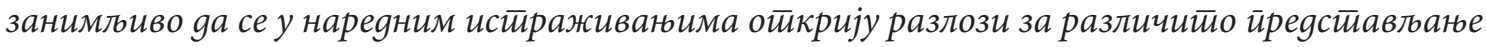

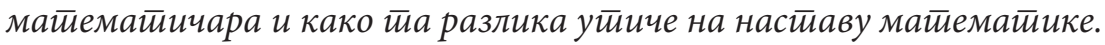

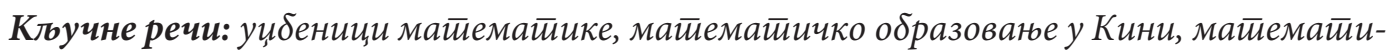

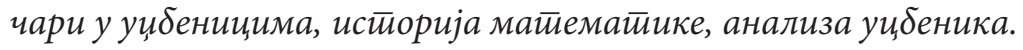

